NBER WORKING PAPER SERIES

\title{
LONG-TERM EFFECTS OF THE INCA ROAD
}

\author{
Ana Paula Franco \\ Sebastian Galiani \\ Pablo Lavado \\ Working Paper 28979 \\ http://www.nber.org/papers/w28979
NATIONAL BUREAU OF ECONOMIC RESEARCH
1050 Massachusetts Avenue
Cambridge, MA 02138
July 2021

The views expressed herein are those of the authors and do not necessarily reflect the views of the National Bureau of Economic Research.

NBER working papers are circulated for discussion and comment purposes. They have not been peer-reviewed or been subject to the review by the NBER Board of Directors that accompanies official NBER publications.

(C) 2021 by Ana Paula Franco, Sebastian Galiani, and Pablo Lavado. All rights reserved. Short sections of text, not to exceed two paragraphs, may be quoted without explicit permission provided that full credit, including ( $)$ notice, is given to the source. 
Long-term effects of the Inca Road

Ana Paula Franco, Sebastian Galiani, and Pablo Lavado

NBER Working Paper No. 28979

July 2021

JEL No. O1

\section{ABSTRACT}

The Inca Empire was the last of a long series of highly developed cultures in pre-colonial South America. It stretched across parts of the current territories of Argentina, Bolivia, Chile, Colombia, Ecuador and the whole of Peru. The Inca Road was its 30,000-kilometer-long transportation system. The aim of this study is to identify its long-term impact on current development in Peru. Our results show that the long-run effect of the Inca Road includes increases in wages and educational attainment, a reduction of child malnutrition and an increase in children's mathematics test scores. We also find that these effects are around $20 \%$ greater for women and explore the mechanisms that may account for this pattern.

\author{
Ana Paula Franco \\ Department of Economics \\ apfrancoc@gmail.com \\ Sebastian Galiani \\ Department of Economics \\ University of Maryland \\ 3105 Tydings Hall \\ College Park, MD 20742 \\ and NBER \\ galiani@econ.umd.edu
}

Pablo Lavado

Centro de Investigación de la Universidad

del Pacífico

Universidad del Pacífico

Av. Sánchez Cerro 2050

Jesús María Lima, Perú

p.lavadopadilla@up.edu.pe 


\section{INTRODUCTION}

The Inca Empire was the last and greatest in a long series of highly developed cultures in pre-colonial South America. It governed a population of some 12 million people and stretched across parts of the current territories of Argentina, Bolivia, Chile, Colombia and Ecuador and the whole of Peru. Its capital was Cusco, Peru. In 1532, the Inca Empire was conquered by the Spanish when Francisco Pizarro executed the last Inca emperor. As in every case when one peoples or civilization conquers another, the arrival of the Spaniards was a protracted and troubled process. The Incas put up resistance during the following 300 years, especially in the Andes (Hyslop, 2014). Thanks to their tenacious struggle to keep their indigenous cultures alive, some Incan customs and institutions have survived to the present day. As just one example, the language of the Incan Empire Quechua- is the second most commonly spoken language in Peru today and is used by around $20 \%$ of the current population. The political boundaries of the Empire are still the basis of many modern-day provinces and districts, and part of the Empire's road system is still used today as a transport and communications network (Hyslop, 2014).

The Inca Road has played a particularly important part in the region's history. Not only did it play a major role during the Inca Empire, but it was also a key component of the economy when most of South America was under Spanish rule. Unlike the Inca's agriculture or language, the Spaniards incorporated the road system into their trade-based economy and merged it with their own institutions. It was thus a linchpin of the colonial economyin the new world (Glave, 1989).

In view of the role that the Inca Road has played in both the past and present, it is striking that its impact on current development has not been studied in greater depth, especially since the economic literature has already established the fact that historical institutions can have long-lasting effects. We contribute the literature on this subject by undertaking the first empirical examination of how the Inca Road has shaped the subsequent economic development process. Our results show that the historical presence of the Inca Road has improved educational, development and labor outcomes: it has increased the average level of educational attainment by 1 year and decreased stunting among children by $5 \%$. Our results also show that the long-term effect of the existence of the Inca Road has been to boost average hourly wages by $20 \%$ and to reduce informality by 6 percentage points. Moreover, as we have also found that these effects are around $40 \%$ greater among womn we have explored a number of potential mechanisms that could account for this pattern.

Our study contributes to the literature on ancient infrastructure's long-run impact on economic development (Spolaore and Wacziarg, 2013; Nunn, 2014; and Ashraf and Galor, 
2018). This literature has largely been concerned with the impact of the provision of public goods over long periods of time. Dalgaard et al. (2019), for instance, explore the link between infrastructure investments made during antiquity and economic activity in Rome. They identify the emergence of market towns from the early medieval period to the modern era as a robust and economically meaningful mechanism that reflects the persistent effects of the Roman road network on economic activity.

Banerjee et al. (2018) investigate the effects of access to transportation infrastructure on economic development during the two decades of rapid GDP growth that occurred in China after it opened up to world trade and undertook market reforms. They find that regions closer to historical transportation networks have higher levels of GDP per capita, greater income inequality, a larger number of firms and higher average profits. Along these same lines, Bosker et al. (2013), who study determinants of urban growth between 800 and $1800 \mathrm{CE}$, document their finding that cities located at intersections of Roman roads expanded in Europe, but not in North Africa or the Middle East.

Our paper also contributes to the literature on the role of pre-colonial forms of organization in Latin American development. The literature on historical institutions has mainly focused on colonial institutions. This holds true for Africa (see Michalopoulos and Papaioannou, 2013; Englebert, 2000; and Bolt and Bezemer, 2009) and also for Latin America (see Angelesand and Elizaldey, 2017; Arias and Girod, 2011; and Acemoglu et. al. 2001). Dell (2010) explores the negative influence of one of the most important colonial institutions, the mining mita. Our paper takes one step further back into Peruvian history.

Despite this vast body of literature, the role of pre-colonial forms of organization has been explored less thoroughly and has mainly focused on African development (see Nunn, 2008). For Latin America, in general, and Peru, in particular, almost no evidence on precolonial institutions has been gathered. Based on the evidence for Africa, we strongly suspect that Latin American pre-colonial institutions account for a large part of the differences observed in current national and regional development processes. If this assumption proves to be correct, then setting the colonial period as the starting point for a study of the development process is a mistake. That is our main contribution to this literature.

Finally, our paper also contributes to the literature regarding the persistence of the gender roles that have been shaped by historical cultural beliefs about the appropriate role of women. In that regard see Alesina et. al. (2013), who explore differences between countries, while our paper focuses on a single country.

The rest of the paper is organized as follows. Section 2 provides a historical overview. 
Section 3 presents the data and the identification strategy that were used, along with some suggested mechanisms. Section 4 looks at women's empowerment as another possible long-term outcome of the existence of the Inca Road. Section 5 concludes the study.

\section{HISTORICAL OVERVIEW}

\subsection{The Inca Empire}

The Inca Empire arose in the second half of the 15th century. It was the last and most vast dominions in a long series of highly developed pre-colonial cultures and states that emerged in the Andes of South America. Its capital was located in Cusco, residence of the Inca rulers. According to Beck (1979), the Inca Empire originated in the Sacred Valley of the Incas, also known as the Urubamba Valley, near Cusco after the Incas defeated the Chancas. In the wake of that victory, the conquest of neighboring peoples was begun and pursued by different Inca Emperors over the next 100 years or more.

The Inca Empire expanded rapidly (Rostworowski, 1999) by peaceful means. It entered into reciprocal relationships with the leaders of other communities, and those leaders usually accepted the conditions offered to them in exchange for protection. The Empire taxed its conquered populations, with that tax being paid mainly in farm products and labor for construction and maintenance of public goods. The economic system of the Inca Empire was based on agriculture and livestock (Pease, 2007).

In such an exchange-based economy, a communications network was of key importance. This network was the main road system of the haEmpire, known as the "Inca Road". It covered around 30,000 kilometers and ran through parts of Colombia, Ecuador, Peru, Bolivia, Chile and Argentina. It was a complex transportation and communications system which was also a ubiquitous symbol of the Inca Empire's power and authority (Hyslop, 2014). One interesting feature of the Inca Road was the presence of tambos. As the people who used the roads had bwalk long distances from one community to another, the Empire set up small warehouses called tambos next to the road every 15 or $20 \mathrm{~km}$ (see Figure 1). Traveling officials, messengers (chasquis) and troops were given food and water at these warehouses. The Inca were not a commercial society, and these provisions were therefore not sold but rather simply distributed.

The location of the Inca Road was determined by social, economic and geographical factors. One of those factors was the Empire's need to be able to reach the communities that it had conquered. The road system was intended to facilitate the movement of troops, official travelers and messengers (chasquis) from and to these differentcommunities, so the road was constructed to pass close by important towns. Another purpose was for the 
transportation of goods such as metals and farm products, so the system incorporated the routes required to reach all key production sites. The Empire also avoided certain kinds of geographic regions: deserts (stretches of more than $100 \mathrm{~km}$ in length where there was no water, high elevations (over 5,000 meters above sea level) and rivers. The roads were straight wherever possible in order to shorten the distances between one location and another (Hyslop, 2014). The construction and placement of the roads were therefore by no means random but instead followed specific geographic and economic patterns that correlated with the pre-road development of the Empire.

The Spanish Crown's conquest of the Inca Empire in 1532-1533 turned the Incas and the peoples that they had subjugated into a source of free labor for the Spaniards. The Crown grouped the indigenous population into settlements (reducciones), each of which was placed under the charge of a Spanish official. That official could then use that labor force for farming or silver mining (Glave, 1989), which soon became leading economic activities. By royal decree, one seventh of the indigenous population was put to work in the mercury mines at Huancavelica and the silver mines in Potosí. This forced labor system was known as the mining mita. The newly created cities near these mines required consumer products, and agriculture therefore shifted from being an activity that was primarily for own consumption to a commercial one. The Spanish used the indigenous labor force to produce a wide range of goods, such as grains, coca and wine, in large quantities. To bring the products to the cities, the new trade-based economy required an efficient road system, and the Inca Road, with its tambos, was the basis for it (Glave, 1989). The fact that the Inca Road was of crucial importance not only during the Inca Empire but also during the 300 years of Spanish colonization that followed it suggests that it may well have had a long-lasting effect on the development of the region.

\subsection{The Inca Road}

The period of the Inca Empire. Once the Incas had begun to conquer other regions of South America, they also came to control road construction. From that time on, the road network expanded exponentially until it came to cover as much as possibly 60,000 kilometers. These great road works were begun by the express order of the Inca Pachacutec. He saw that roads were needed to maintain control over the Empire's conquered territories, and that control was secured by enabling officials and troops to move more quickly to where they were needed. Yet the road network was essential not only to permit the movement of armies and officials but also to facilitate the mobilization of the mitimaes (ethnic groups relocated by the Incas as a matter of policy), the transport of products to Cusco that had been harvested in territories conquered by the Incas (which were stored in the tambos along the way) and the work of messengers (chasquis) (Rostworowski, 1988). 
The colonial period. The Inca Road was built to serve the Inca Empire's political and military interests. Trade did not exist at the time that the road system was built, so the system did not originally have a commercial purpose, but that quickly changed with the arrival of the Spaniards in 1532. One of the Spanish Crown's main economic objectives was to mine gold and silver and export it to Europe (Glave, 1989). As a result, the burgeoning mining industry that arose during the early years of the colonial period was accompanied by a trade boom (mainly trade in food) centered around the newly founded highland mining cities of Huancavelica and Potosí. ${ }^{2}$ Before the Spaniards' arrival, the Inca had practiced subsistence farming; communities were located in fertile areas and grew enough food crops to meet the needs of their members and to barter for the produce of other communities. The Incas did not have a currency. After the Spanish Conquest, one seventh of the indigenous population was relocated to these cities to work in the mines. The Spaniards who were placed in charge of the mining economy also relocated there, giving rise to a demand for a range of agricultural products, such as grains, coca and wine, that were produced alower altitudes. This created a market for these products that spanned the territory controlled by the Spanish.

\section{THE INCA ROAD AND DEVELOPMENT}

We estimate the long-term effect of the Inca Road by testing whether residence close to the road has influenced today's development outcomes.

\subsection{Data}

Our first source of data is a map provided by the Ministry of Culture of Peru of the original Inca Road that dates back to the pre-colonial period. As shown in Figure 1, the road (in yellow)

crossed the country vertically from north to south. The triangles on the map showthe positions of the tambos, (small public warehouses), which have been georeferenced from aerial photos.

To estimate the long-term effects of the presence of the Inca Road, we construct a treatment variable that reflects whether a person lives close to the route of the Inca Road or not. In order to do this, we divide Peru's territory into grids cells and assign a value of 1 to grid cells crossed by any portion of the road system (our treatment group) and a

\footnotetext{
${ }^{2}$ During the period of the Inca Empire, mining did exist, but silver and gold had only an ornamental use.
} 
value of 0 to the adjacent cells (our control group).

To measure development outcomes, we use three independent datasets. Our outcomes of interest are measures of schooling, labor and health. First, to obtain schooling and labor outcomes, we use the results on living conditions from the representative National Household Survey (ENAHO) carried out by the National Institute of Statistics and Informatics of Peru (INEI) for the period from 2007 to 2017. Sampling of households is done at the regional level, which is the country's first-level administrative division. We use a pooled cross-sectional dataset to obtain observations and representativeness at a more disaggregated level. Data since 2007 is used because that was the first year that the survey included the latitude and longitude of each household's block in urban areas and town in rural areas, which allowed us to georeference each household's location. We focus on ENAHO's labor (hourly wages) and schooling (years of schooling) modules for our main outcomes of interest. This data is collected for individuals over 15 years of age (the legal working age in Peru). As we are dealing with a pooled dataset, wages are adjusted by inflation and expressed in 2007 Peruvian soles. We also take other sociodemographic controls from ENAHO, such as the main language spoken by an individual, age and relation to the head of household. 


\section{Figure 1: Route of the Inca Road in Peru}

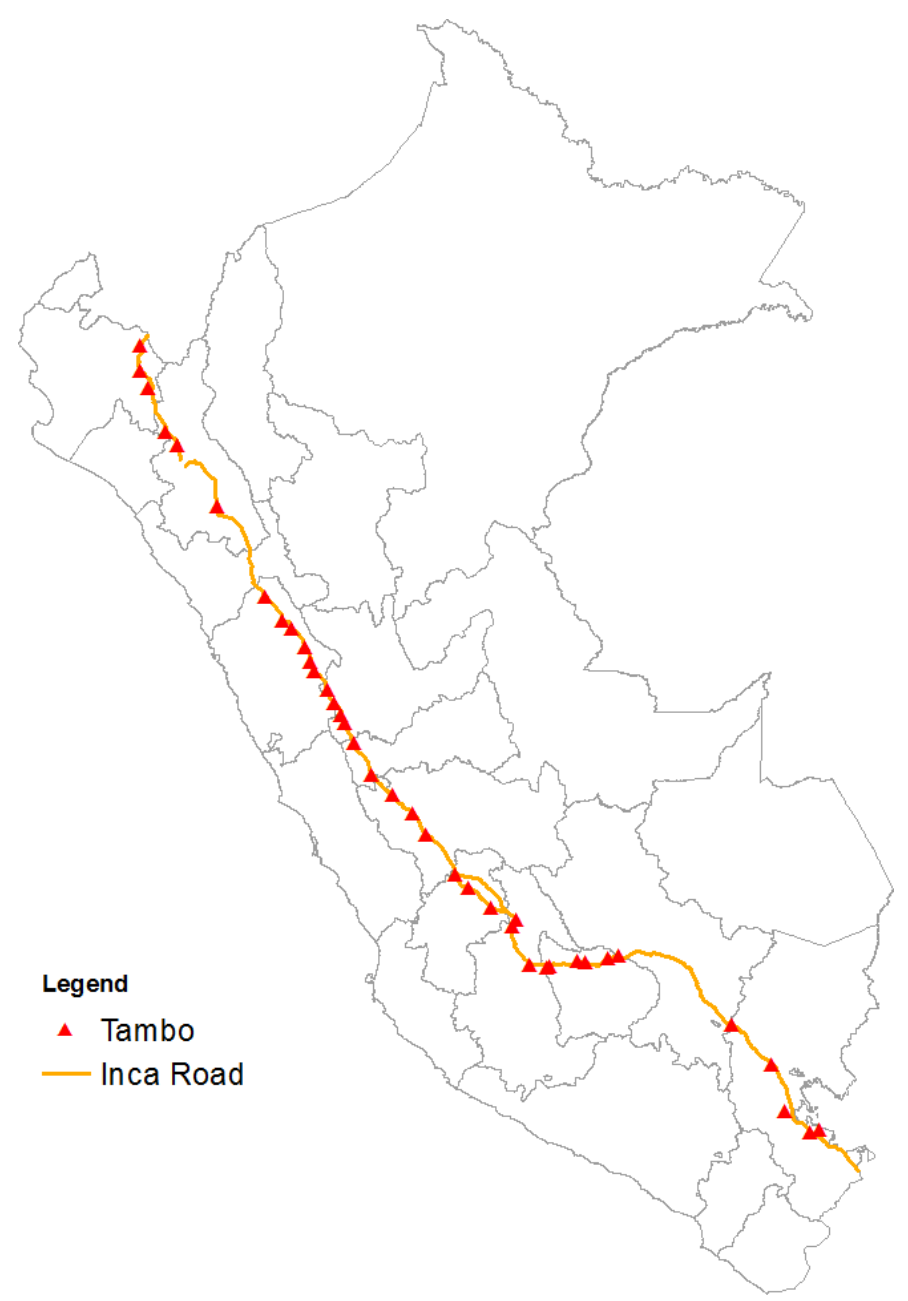

We then use a microcensus dataset, the 2005 National Height Survey, which is conducted by the Ministry of Education in the country's schools. According to the World Health Organization, children are classified as malnourished if their height is more than two standard deviations below that of their age-cohort median. This data yields a measurement of stunting, which is also related to development. Another microcensus dataset from the Ministry of Education, the 2015 National Student Census, is also used. Every student enrolled in the second grade of primary school (ages 7-8) must take a mathematics test and a language test. We use the standardized mathematics scores as another development outcome.

For each of these three datasets, we georeferenced the household's or school's location and 
determine whether individuals live or study in an area close to what was once the Inca Road. This allows us to merge our treatment variable with our development outcomes.

Finally, working with spatial data requires the use of geographic controls to account for potential confounders (i.e. geographic variables that correlate with the Inca Road and may also correlate with development outcomes). Specifically, we include controls for elevation, slope and the distance to rivers. To obtain the elevation, we use NASA's Shuttle Radar Topography Mission (SRTM) data on elevation for 30 arc-second by 30 arc-second (approximately $1 \mathrm{~km}$ by $1 \mathrm{~km}$ ) grid cells. Elevation data is sufficient to derive slope data at the same resolution. We then collapse the SRTM data to obtain an average of the elevation and slope at our grid cell level. Elevation is measured in meters above sea level, and slope is measured in degrees. To obtain the shortest distance to a river, we use the hydrographic map of the National Water Authority of Peru, which plots the location of every river in the country. We then construct a variable which accounts for the shortest distance from the household's block to a major river. This variable is measured in kilometers.

\subsection{Empirical Strategy}

In order to estimate the long-term effects of the Inca Road, we construct a valid counterfactual for the households classified as having been impacted by it. We do so by delimiting our study area based on the areas in the proximity of the Inca Road where all relevant development characteristics prior to the road system's construction were similar. In order to use this approach, we need to define our sampling strategy. We explore areas of different sizes and ultimately divide the territory of Peru into grid cells measuring $10 \times 10 \mathrm{~km}, 15$ x $15 \mathrm{~km}, 20$ x $20 \mathrm{~km}$ and 25 x $25 \mathrm{~km}$. Our main focus is on the $20 \times 20 \mathrm{~km}$ grid cells, however, because this is the average size of the districts, which are the smallest administrative division in Peru. Thus, we expect theimpacts of the Inca Road (if any) to be spread across an area equivalent to the area of a district. We use the other grid cell sizes to explore the robustness of our results.

Figure 2 shows our empirical strategy in graphic form using the ENAHO dataset. We define grid cells crossed by the road as the treatment group (in red) and adjacent grid cells as the control group (in green). Households (in blue) that are located within the treatment grid cells become our sample of treated households and those located in the 
control grid cells become our control households.

\section{Figure 2: Treatment and Control Groups in the proximity of the Inca Road}

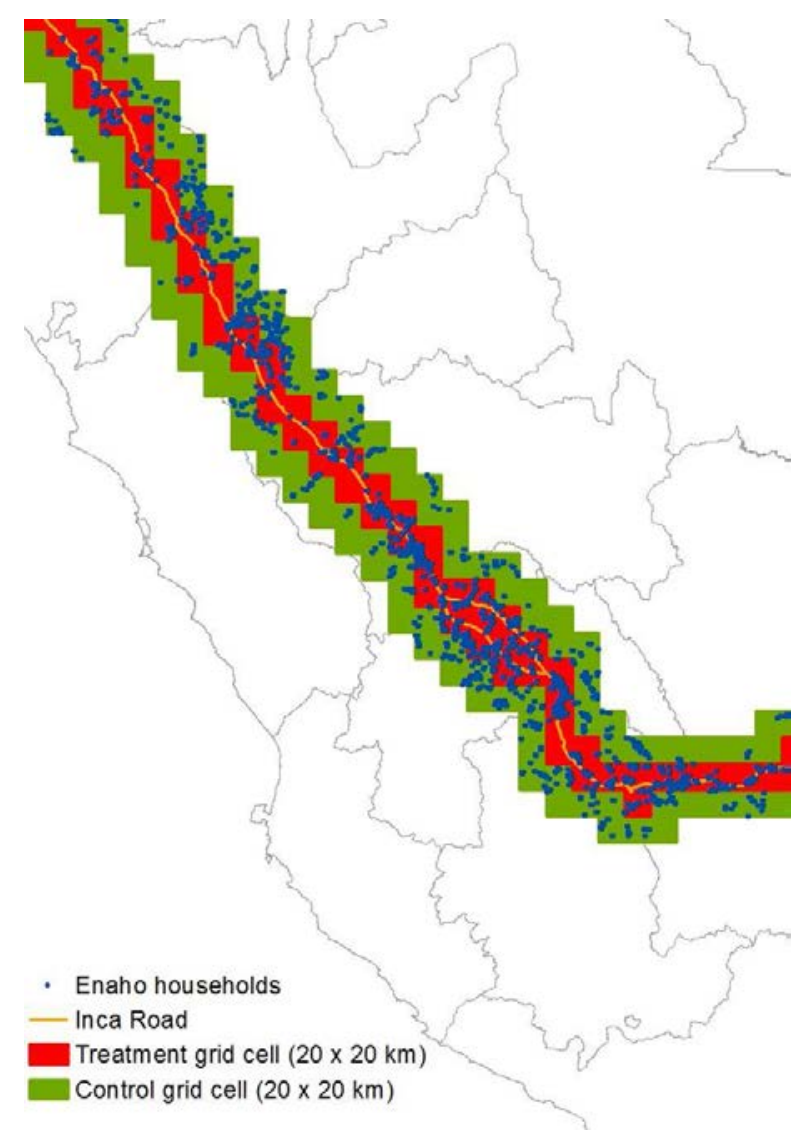

Empirically, we implement this approach by estimating the following regression model:

$$
y_{i g}=\alpha_{0}+\alpha_{1} \operatorname{Road}_{g}+X_{g}^{G^{\prime}}+X_{i}^{D^{\prime}} \Pi+\epsilon_{i g}
$$

where $y_{i g}$ is the development outcome of interest for individual $i$ living within the grid cell $g$. $\operatorname{Road}_{g}$ is an indicator variable that takes the value of 1 if the individual lives in a treated grid cell. $\mathrm{X}^{G}$ is a vector of the ${ }^{g}$ geographic covariates of the grid cell $g$ (i.e. elevation, slope and density of rivers) and $\mathrm{X}^{D}$ is a vector of the demographic variables for individual $i$ (i.e. age, gender and ethnicity). The parameter of interest is $\alpha_{1}$, which captures the longterm effect of the presence of the Inca Road on the outcome of interest.

After defining our grid cells, in order for $\alpha_{1}$ to be identified, we need to ensure that the 
pre-treatment characteristics in terms of development outcomes of our treatment and control grid cells are similar. Thus, we now test for differences in observable characteristics that may have affected the pre-Inca-Road economic development and demographics of the treatment and control communities.

It has been established that agriculture was the most important economic activity of the Incas (see the extensive work of Murra (1956) and Hyslop (2014) on the Inca economy) and that the main environmental factors that influence the productivity of agricultural crops are soil quality (nutrients and access to water sources) and climate (temperature and precipitation) (see Chang, 1968, and Howden et al., 2007, among others). Climate conditions, in turn, are mainly determined by an area's altitude, longitude and latitude. As geographic characteristics are hard to modify, we argue that areas with similar geographic characteristics — and thus similar agricultural productivity levels — had similar levels of development before the Inca Road was built. 


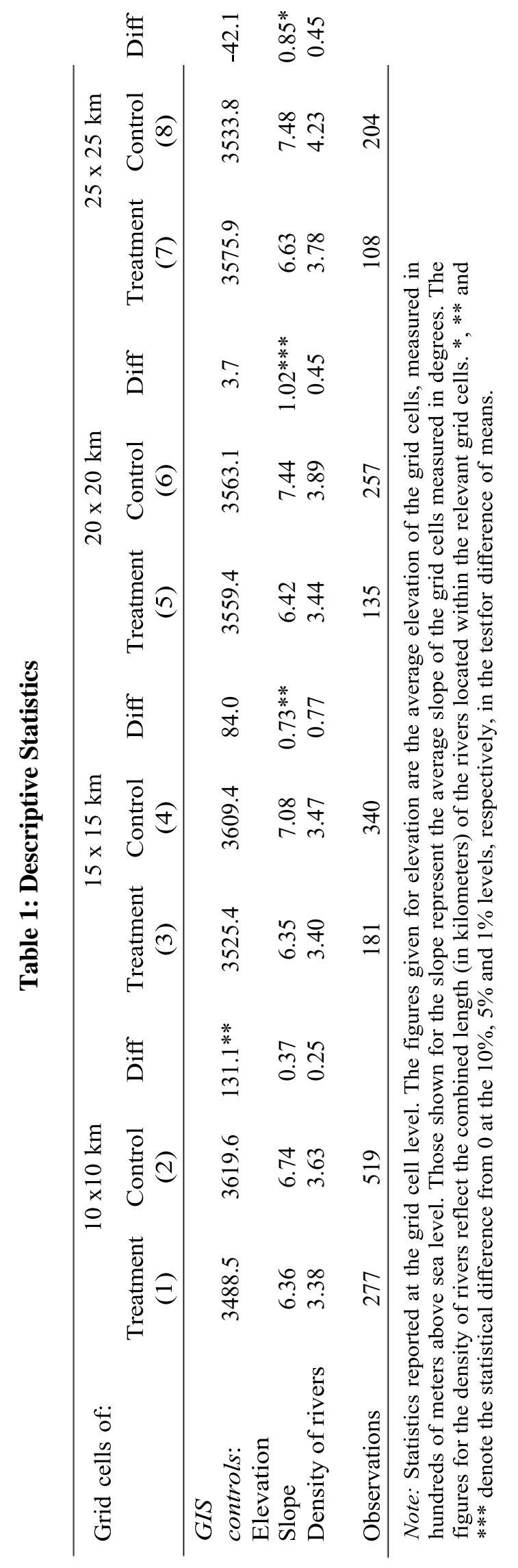


In Table 1, we compare the average value of environmental characteristics across the treatment and control groups. These estimates already control for latitude and longitude, since we have chosen adjacent grid cells, so we focus on elevation, slope and density of rivers. The figures for elevation are the average elevation of the grid cell, measured in meters above sea level; those shown for slope are the average values of the slope in the grid cell, which is measured in degrees; and the values shown for the density of rivers denote the combined length (in kilometers) of the watercourses of all sizes in the grid cell. Overall, we find that differences in geographic conditions are not statistically distinguishable across the treatment and control groups, which suggests that pre-treatment development trends for the two groups were probably similar. There are relatively small but nonetheless significant differences in the average slopes for the $15 \times 15 \mathrm{~km}, 20$ x 20 kmand $25 \times 25 \mathrm{~km}$ grids cells. To account for these differences, we include slope as a control in our estimates.

It is important to point out that environmental conditions - especially access to fresh water- predicted not only development levels but also demographic trends. Cook (1981), a historian who has studied the pre-Conquest population of Peru extensively, argues that "the density of the [Inca] population was ultimately limited by the environment's ability to sustain them". Table 1 shows that differences in the density of rivers are not distinguishable across the treatment and control groups. We further test these differences by calculating the shortest distance from the center of the grid cell to the closest river and the mean of the shortest distance from current households' locations to the closest river at the grid cell level. For these measures, we also find that differences across the treatment and control grid cells are not statistically distinguishable, suggesting that the distribution of the population is homogeneous throughout our sample.

\subsection{Results}

Table 2 reports the association between the Inca Road and current development outcomes. Based on the pooled household survey dataset, Column 1 shows a positive and statistically significant relationship between the Inca Road and hourly wages, with residence within 20 $\mathrm{km}$ of the Inca Road increasing hourly wages by around $10.5 \%$ (standard error $=3.7 \%$ ) in 2007-2017. This effect is as large as that of an additional year of schooling. The specification is estimated at the worker level and includes survey year fixed effects, regional fixed effects and demographic controls (i.e. gender, age and schooling). 
To ensure that we are actually capturing the effect of the Inca Road and not the effect of other geographic variables, we include the average elevation and slope, as well as the density of rivers in the $20 \times 20 \mathrm{~km}$ grid cell. Our estimate remains statistically significant and economically relevant after the inclusion of these geographic variables, which indicates that they are not driving our results (see Column 2). This finding is also robust when using the $10 \times 10,15 \times 15$ and $25 \times 25 \mathrm{~km}$ grid specifications (see Table A1 in the appendix).

Along the same lines, Columns 3 and 4 (based on census data) show a negative and significant relationship between the Inca Road and child malnutrition, which is an informative measure of living standards. For children between 6 and 9 years of age, attendance at a school located within $20 \mathrm{~km}$ of the In c a Road reduced the probability of being malnourished by 3.4 percentage points ( standard error $=1.2 \mathrm{pp}$ ), a reduction of around $8 \%$, in 2005. The base specification (Column 3) is estimated at the school level and includes regional fixed effects. As with wages, estimates are robust to the inclusion of geographic controls (see Column 4) and to different grid cell size specifications (see Table A1).

Using pooled household survey data and the national mathematics assessment scores, Columns 5-8 report a positive effect of proximity to the Inca Road on educational outcomes. Estimates are significant and economically relevant. For instance, residence within $20 \mathrm{~km}$ of the Inca Road increases schooling by 1.64 years (standard error $=0.34$ ); this is a sizeable increase, since it is equivalent to $22 \%$ of the average years of schooling of our sample (7.41 years). Moreover, attendance at a school located within $20 \mathrm{~km}$ of the Inca Road increases the math test scores of 7-year-olds by 0.256 standard deviations. These estimates are robust to the inclusion of geographic controls and (see Table A2) to $10 \times 10$, $15 \times 15 \mathrm{~km}$ and $25 \times 25 \mathrm{~km}$ grid specifications. 


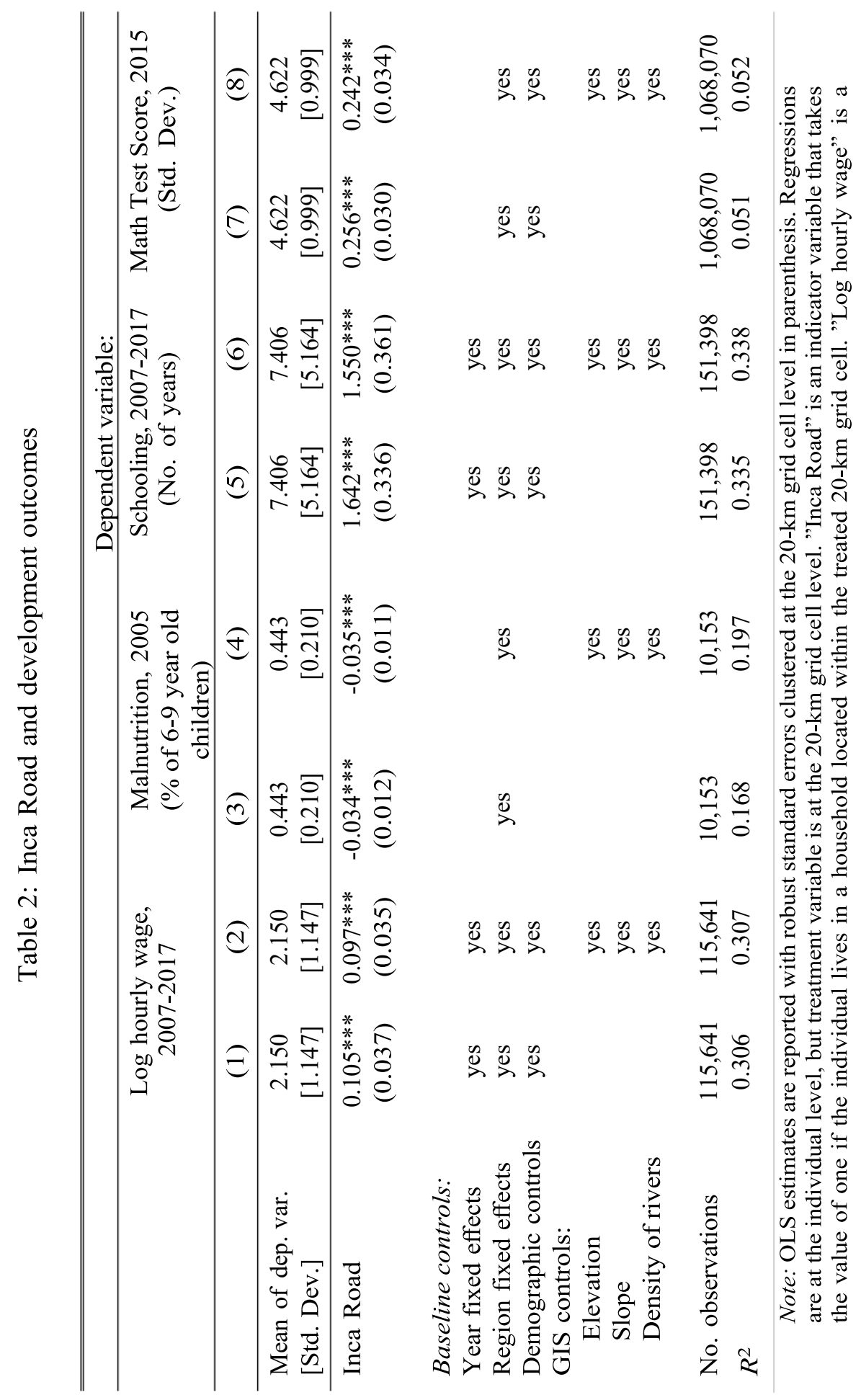


Up to this point, our estimates have shown that there is a positive association between proximity to where the Inca Road used to be and current labor, education and nutrition outcomes, which points to the presence of a persistent effect on within-country development. However, there is still the question as to what the channels of that persistence are. While acknowledging that several different factors could be playing a role, in this section we highlight the role of two main factors: access to public goods and clear property rights during the Spanish colonial period. We hypothesize that, given the increase in mining and trade that occurred after during the years following the conquest, residence closer to the road became important. Thus, Spanish conquerors chose to settle near the road and promoted the construction of roads and schools in those areas (the public goods channel). When they decided to settle close to the road, they brought the formal property rights system used by the Spanish Crown with them - which, in turn, fostered private investment - in those areas (the property rights channel).

As explained in Section 2, one of the Spaniards' main economic objectives was to extract and export gold and silver to Europe (Glave, 1989). They relied on the Inca Road for transporting gold and silver from the newly founded mining cities of Huancavelica and Potosi in the highlands to the coast, from where they then shipped these precious metals to Spain. Indigenous groups were relocated to these cities to work the mines. The Spaniards who were placed in charge of the mining economy also settled in these areas and generated a demand for various agricultural products, such as grains, coca and wine, that were produced at lower altitudes. As the Inca Road already traversed the Andes from north to south, it became the link between the highland mining cities and the rest of the Spanish Empire. Thus, the Spaniards changed the purpose of the Inca Road from political and military to commercial and export uses (Hyslop, 2014).

The enhanced importance of the Inca Road encouraged the early Spaniards to settle nearby. The Spanish Crown granted tracts of land as recompense to Spaniards who had fought during the conquest. These grants included title to the land and the right to collect a tax in the form of labor or crops from the indigenous population living on that land. Thanks to the mining boom, the land surrounding the Inca Road acquired greater value (Keith, 1971). The way that the tambos evolved illustrates that nature of this shift, as these small warehouses, which had once been centers that gave free food and water to the passing Inca officials and troops, were converted into centers that sold food and products to anyone who used the road. And the people living close to the Inca Road were the ones who 
conducted these commercial activities. Thus, it was profitable to live near the road. The tambos became so successful that the Spaniards began to build new private warehouses along the Inca Road as well (Glave, 1989).

To secure these investments, Spaniards sought to establish clearly delimited property rights in the areas close to the Inca Road where they decided to settle (Glave, 1989). On the other hand,historians agree that areas where the Spaniards did not settle (i.e. areas farther away from the road) served as escape routes and havens for the indigenous population, many of whom broke free from the dominion of the Spanish Crown by hiding in the highlands, which, at the time, had no roads that linked them to the lowlands (Silverblatt, 1978). Those who escaped sought to live as they had before, returning to their communal living arrangements and subsistence agriculture; property rights did not exist in these areas.

Property rights have been identified as key drivers of economic development and poverty reduction (see, among others, North, 1981; Besley, 1995'; Field (2007), Galiani and Schargrodksy, 2010). Investment incentives are the main channels for these effects, as people are not willing to invest when the returns on their investments are not secure. Thus, when property rights are secure, households can be expected to spend less time and money protecting their land and to allocate those resources more efficiently (e.g. by working or studying more hours). We therefore hypothesize that the establishment of formal property rights in areas close to the Inca Road may have set the stage for the future development of those areas. 


\section{Table 3: Mechanisms}

\begin{tabular}{lccc}
\hline \hline & \multicolumn{3}{c}{ Dependent Variable: } \\
\cline { 2 - 4 } & Roads & Schools & Property rights \\
& $(1)$ & $(2)$ & $(3)$ \\
\hline Mean of dependent & 0.260 & 22.143 & 60.980 \\
variable & & & \\
[std. dev.] & {$[0.210]$} & {$[24.860]$} & {$[66.652]$} \\
\hline Inca Road & $0.082^{* * *}$ & $18.009^{* * *}$ & $48.015^{* * *}$ \\
& $(0.024)$ & $(2.475)$ & $(6.641)$ \\
Baseline controls: & & & \\
GIS controls: & & & yes \\
\multicolumn{1}{c}{ Elevation } & yes & yes & yes \\
\multicolumn{1}{c}{ Slope } & yes & yes & yes \\
Density of rivers & yes & yes & 392 \\
No. Observations & 320 & 392 & 0.160 \\
$R^{2}$ & 0.073 & 0.162 & \\
& & & \\
\hline \hline
\end{tabular}

Note: OLS estimates are reported with robust standard errors clustered at the $20-\mathrm{km}$ grid cell level in parentheses. Regressions are at the grid cell level, and the treatment variable is at the $20-\mathrm{km}$ grid cell level. "Inca Road" is an indicator variable that takes the value of 1 if the grid cell is crossed by the Inca Road. For the GIS controls, the entries for elevation (x100) report the average elevation of the 20$\mathrm{km}$ grid cells, measured in hundreds of meters above sea level. The entries for slope report the average slope of the $20-\mathrm{km}$ grid cells, measured in degrees. The heading "Density of rivers" refers to the combined length in kilometers of rivers located within the $20-\mathrm{km}$ grid cell. $*, * *$ and $* * *$ indicate significance at the $10 \%, 5 \%$ and $1 \%$ levels.

Furthermore, in addition to the influence exerted by the private sector, there is evidence that Spaniards lobbied for the provision of public goods in the areas where they settled, and this, too, may have helped to drive the economic development of areas close to the Inca Road (see Quiroz, 2008, and Stein, 1980). 
With respect to the property rights channel, data from the pooled household survey indicates that there is a positive association between the Inca Road and current property rights (see Column 1 of Table 3). Residence within $20 \mathrm{~km}$ of the Inca Road in 2007-2017 significantly increased (by 8.2 percentage points) the probability of an individual holding property rights (ownership) to his or her land. This impact is sizeable, since only $26 \%$ of our sample own their homes; this means that the increase attributable to the Inca Road amounts to $31 \%$. This regression is robust to the inclusion of geographic characteristics.

With respect to the public goods channel, our results point to a significant and positive association between the Inca Road and the current provision of two main public goods: primary schools and roads (see Columns 2 and 3 of Table 3) The 20-km grid cells that are crossed by the Inca Road have an extra $18 \mathrm{~km}$ of road density, which is equal to $82 \%$ of the average road density in our sample. In the same vein, we find that grid cells crossed by the Inca Road also have an additional 48 primary schools, for an increase of $79 \%$ over the sample average (61 primary schools). As a result, we find that the provision of public goods in areas close to the Inca Road is about $80 \%$ higher than in areas farther from it. Both of these specifications are robust to the inclusion of geographic controls.

\section{WOMEN AND THE INCA ROAD}

Historical sources agree that indigenous women played a more active role in the trade economy that arose near the Inca Road during the colonial period than other women who lived farther from it. Based on the evidence of stickiness in gender roles, we hypothesize that the Inca Road may explain differences in current female labor outcomes and degrees of empowerment.

Besides having to pay a tax in the form of labor to the Spanish conquistadors, every indigenous community had to take part in the mining mita established by the Spanish Crown, which was a forced labor system that required indigenous communities to send one seventh of their adult male population to work in the mines in Potosí and Huancavelica. Along with other factors, such as pandemics, the mita had a strong impact on the indigenous male population (Cook, 1981). Although women were theoretically not allowed to participate in the main economic activities pursued during the colonial period, in actual fact they did do so in order to make up for the work left undone by the men who had to go work under the mita system (Glave, 2009). Thus, residence near the Inca Road 
translated into a heavier workload for the indigenous population in those areas because they had to oversee the maintenance of the roads and the sale of goods at the tambos (in addition to the farm work that was done there as everywhere else).

Indigenous women were the ones who absorbed the additional work in the tambos (Chacaltana Cortez, 2016), which involved frequently interacting with travelers, most of whom were Spanish merchants. As a result, indigenous women living near the Inca Road learned how to speak Spanish and how to use the Spanish currency before their male counterparts did (Chacaltana Cortez, 2016). It is well established in the historical literature that the women who worked in the tambos played a key role in the trade-based economy of that period.

It is also well established in the economics literature that working outside the home increases women's bargaining power and their empowerment, tipping the balance toward more egalitarian cultural gender roles and beliefs about the appropriate role of women in society. For communities located near the Inca Road, it was common to see women working outside the home in the tambos. These kinds of cultural patterns inherently tend to be sticky: they give rise to easy-to-follow rules of thumb which are useful ways to avoid repeatedly reprocessing similar information time and time again and are thus hard to change (see Alesina et al., 2013; Fortin, 2005; Carranza, 2014; Xue, 2018; and Hansen et al., 2015). We therefore hypothesize that gender roles are more egalitarian in areas closer to the Inca Road simply because people have become more used to seeing women working outside the home in those areas.

To test our hypothesis, we draw on the results of the National Population and Health Survey (NHS) of Peru, in addition to the pooled national household survey dataset mentioned above. This survey, which collects information on women of childbearing age (15-49 years old), is representative at the national level and georeferenced at the block level for urban areas and at the town level for rural areas. More specifically, we focus on the household survey results for schooling and labor outcomes (wages and labor force participation). In the case of the NHS data, we focus on variables related to women's empowerment and, more specifically, on women's age at the time of the birth of their first child, and two measuresof intra-household bargaining power (who makes the most important decisions in the household and who makes health-related decisions). Both measures have been widely discussed in the literature as determinants of women's 
empowerment (on age at first birth, see Chari et al., 2017, and Miller, 2010; on bargaining power, see Field et al., 2019; De Mel et al., 2009; and Ashraf, 2009).

For the household survey, we estimate the following specification:

$$
y_{i g}=\alpha_{0}+\alpha_{1} \text { Road }_{g}+\alpha_{2}\left(\text { Road }_{g} * \text { Female }_{i}\right)+X_{i g}^{\prime}+X_{i}^{D^{\prime}} \Gamma+\epsilon_{i g}
$$

And for the NHS (women only), we estimate the following specification:

$$
y_{i g}=\beta_{0}+\beta_{1} \operatorname{Road}_{g}+X_{i g}^{\prime} \Delta+\epsilon_{i g}
$$

where $y_{i g}$ is the development outcome of interest for individual $i$ living in grid cell $g$ (e.g., schooling, wage, intra-household bargaining power measures). $\operatorname{Road}_{g}$ is a dummy variable that takes the value of 1 if the individual lives in a treated grid cell. $X_{i g}$ is a vector of covariates that includes geographic variables of grid cell $g$ (elevation, slope, density of rivers) and demographic variables of individual $i$ (age and ethnicity). The parameters of interest are $\alpha_{2}$ and $\beta_{1}$, which capture the long-term effect of the Inca Road and the different measures of women's empowerment.

Table 4 presents these estimates. Based on the household survey data, Columns 14 depict a positive association between the Inca Road and female labor outcomes. Women living within $20 \mathrm{~km}$ of the Inca Road have, on average, 1.63 years more schooling than women living farther from it. This represents a sizeable increase (22\%) over our sample mean (7.4 years) and one which outpaces the increase for men. The hourly wages of women who live close to the Inca Road also seem to be higher than those of their counterparts in areas farther from that road system. Even though the estimated levels are not significant, the direction of the coefficient is positive, suggesting that women may be paid better for work performed outside the home in areas close to the Inca Road. These specifications are robust to the inclusion of demographic and geographic covariates.

Columns 5-7 (based on NHS data) show that there is also a positive association between the Inca Road and different measures of female intra-household bargaining power. Residence within $20 \mathrm{~km}$ of the Inca Road reduces the likelihood of being a teenage mother by 1.4 percentage points. It also increases the likelihood that women are the ones who are making health-related decisions for the household by 5.2 percentage points and the likelihood that they are making the decisions about high-value purchases, such as buying a home, by 5.4 percentage points. These increases in the bargaining power of women living 
near the Inca Road over women who reside farther away from it range from $5 \%$ to $22 \%$. The regressions also include demographic and geographic covariates.

\section{CONCLUSIONS}

We estimate the long-term effects of the Inca Road and find a positive and statistically significant relationship between the Inca Road and hourly wages, with residence within 20 $\mathrm{km}$ of the Inca Road increasing hourly wages by around $10.5 \%$ as compared to wages in other areas during the period 2007-2017. This effect is as large as that of an additional year of schooling. Along the same lines, we find a significant negative relationship between the Inca Road and child malnutrition, as attendance at a school located within $20 \mathrm{~km}$ of the Inca Road reduced the probability of being malnourished by 3.4 percentage points (a reduction of around $8 \%$ ) in 2005. In addition, we find a positive effect between the Inca Road and educational outcomes, with residence within $20 \mathrm{~km}$ of the Inca Road increasing the length of schooling by 1.64 years, which equals $22 \%$ of the average years of schooling of our sample (7.41 years).

With respect to the channels of persistence of the effects of the Inca Road, there is a significant and positive association between the Inca Road and the current provision of two main public goods, primary schools and roads. We report that $20-\mathrm{km}$ grid cells crossed by the Inca Road have an extra $18 \mathrm{~km}$ of road density, which equals $82 \%$ of the road density in our sample. Similarly, we find that grid cells crossed by the Inca Road also have an additional 48 primary schools, for an increase of $79 \%$ over the sample average. What is more, we find that there is a positive association between the Inca Road and current property rights. The size of this impact can be appreciated by taking into consideration the fact that only $26 \%$ of the members of our sample own their homes, as this makes the increase attributable to the Inca Road equivalent to $31 \%$.

Finally, we find a positive association between the Inca Road and female labor outcomes. Women who live within $20 \mathrm{~km}$ of the Inca Road average 1.63 more years of schooling than women who live farther from the road system. This is a sizeable increase $(22 \%)$ over our sample mean (7.4 years), and one which outpaces the increase for men. Furthermore, there is also a positive association between the Inca Road and different measures of female intra-household bargaining power. Residence within $20 \mathrm{~km}$ of the Inca 
Road reduces the likelihood of being a teenage mother by 1.4 percentage points. It also increases the likelihood that women are making health-related decisions for the household by 5.2 percentage points and the likelihood that they are making decisions about high-value purchases, such as buying a home, by 5.4 percentage points. 


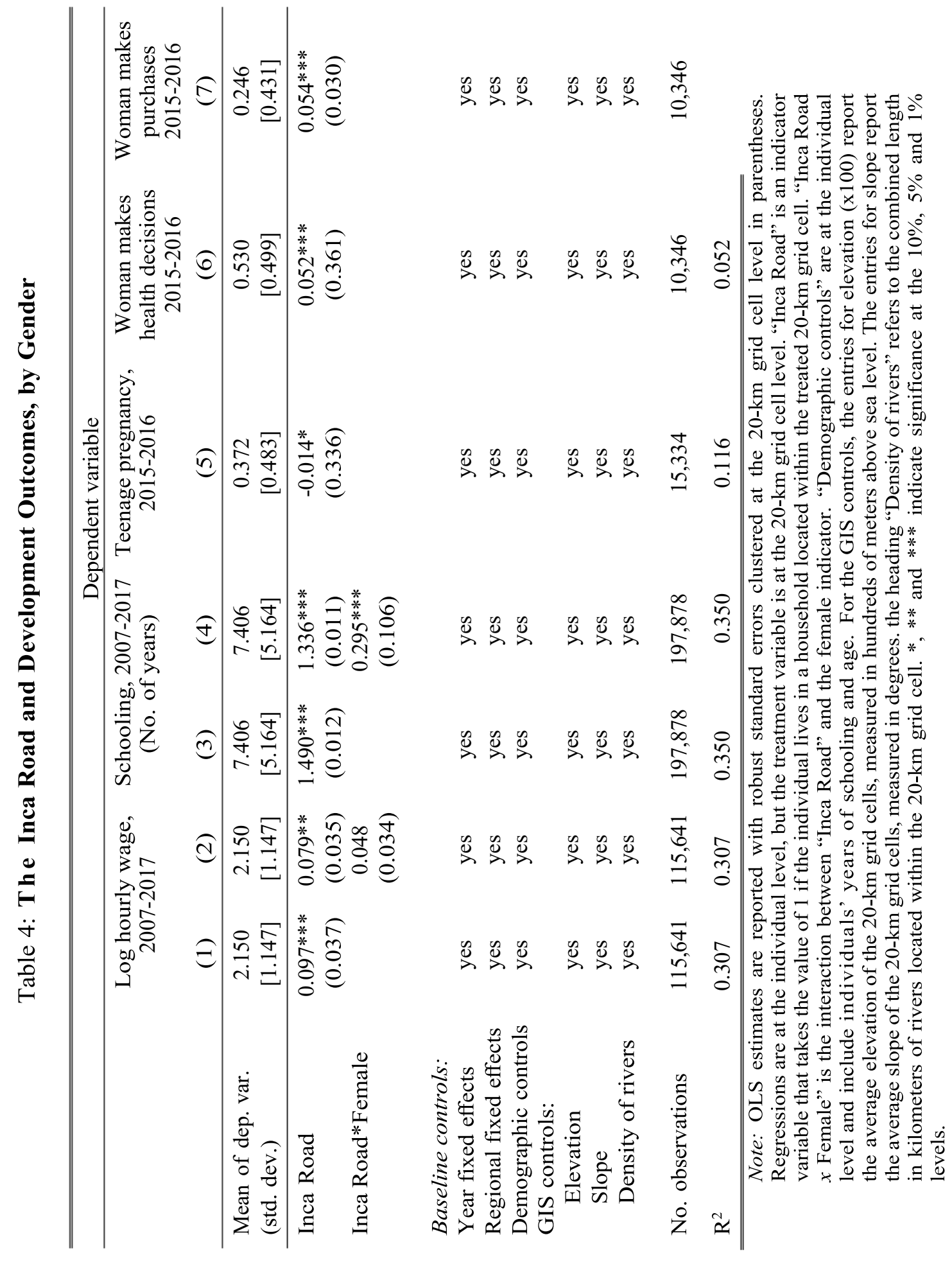




\section{References}

Acemoglu, D., S. Johnson, And J. Robinson (2000): "The Colonial Origins of Comparative Development: An Empirical Investigation," The National Bureau of Economic Research.

(2001): "The Colonial Origins of Comparative Development: An Empirical Investigation," American Economic Review, 91, 1369-1401.

Alesina, A., P. Giuliano, AND N. NunN (2013): “On the Origins of Gender?r?les: Women and the Plough," Quarterly Journal of Economics, 128.

ANGElesand, L., AND A. ElizAldey (2017): "Pre-colonial Institutions and Socioeconomic Development: The Case of Latin America," Journal of Development Economics, 124, 22-40.

ARIAS, L., AND D. GIROD (2011): "Indigenous Origins of Colonial Institutions," Quarterly Journal of Political Science.

ASHRAF, N. (2009): "Spousal Control and Intra-household Decision Making: An Experimental Study in the Philippines," American Economic Review, 99, 1245-1277.

ASHRAF, Q., AND O. GALOR (2018): “The Macrogenoeconomics of Comparative Development," Journal of Economic Literature, 56, 1119-1155.

BANERJEe, A., E. Duflo, AND N. QIAN (2018): "On the Road: Access to Transportation Infrastructure and Economic Growth in China," Journal of Development Economics, 56.

BECK, C. (1979): Ancient Roads on the North Coast of Peru, University of California, Berkeley.

BESLEY, T. (1995): "Property Rights and Investment Incentives: Theory and Evidence from Ghana," Journal of Political Economy, 103, 903-937.

BolT, J., AND D. BEZEMER (2009): “Understanding Long-Run African Growth: Colonial Institutions or Colonial Education?" The Journal of Development Studies, 45, 24-54.

Bosker, M., E. BuRINGH, AND J. L. VAN ZANDEN (2013): "From Baghdad to London: Unraveling Urban Development in Europe, the Middle East and North Africa, 8001800," Review of Economics and Statistics, 94, 1418-1437.

CARranzA, E. (2014): "Soil Endowments, Female Labor Force Participation, and the Demographic Deficit of Women in India," American Economic Journal: Applied Economics, 6, 197-225.

Chacaltana Cortez, S. (2016): “De los tambos incas a las tambarr' 1as coloniales: Economía colonial, legislación de tambos y actividades licenciosas de las mujeres indígenas," Boletín de Arqueología PUCP, 21. 
Chang, J.H. (1968): Climate and Agriculture: An Ecological Survey, Chicago: Aldine.

Chari, A., R. Heath, A. Maertens, And F. Fatima (2017): “The Causal Effect of Maternal Age at Marriage on Child Wellbeing: Evidence from India," Journal of Development Economics, 127, 42-55.

Cook, N. D. (1981): Demographic Collapse: Indian Peru, 1520-1620, Cambridge University Press.

Dalgaard, C., N. KaArsen, O. Olsson, And P. Selaya (2019): "Roman Roads to Prosperity: Persistence and Non-persistence in Public Good Provision," CEPR Discussion Paper 12745.

De Mel, S., D. McKenzie, And C. Woodruff (2009): “Are Women More Credit Constrained? Experimental Evidence on Gender and Microenterprise Returns," American Economic Journal: Applied Economics, 1, 1-32.

Dell, M. (2010): “The Persistent Effects of Peru’s Mining Mita,” Econometrica, 78.

ENGLEBERT, P. (2000): "Pre-colonial Institutions, Post-Colonial States, and Economic Development in Tropical Africa," Political Research Quarterly, 53, 7-36.

FIELD, E. (2007): "Entitled to Work: Urban Property Rights and Labor Supply in Peru," The Quarterly Journal of Economics, 122, 1561-1602.

Field, E., R. PANDE, N. Rigol, S. SCHANER, AND C. TROYER MoOre (2019): “On Her Own Account: How Strengthening Women's Financial Control Impacts Labor Supply and Gender Norms," NBER Working Paper No. 26294.

ForTIN, N. (2005): "Gender Role Attitudes and the Labour Market Outcomes of Women Across OECD Countries," Oxford Review of Economic Policy, 21.

GALIANI, S. AND E. SCHARGRODSKY, "Property rights for the poor: Effects of land titling", Journal of Public Economics, Volume 94, 2010, pages 700-729

GLave, L. M. (1989): Trajinantes. Caminos indígenas en la sociedad colonial siglos $X V I / X V I I$, Instituto de Apoyo Agrario.

(2009): "Propiedad de la tierra, agricultura y comercio, 1570-1700: el gran despojo," Compendio de Historia Económica del Perú. Tomo 2.

Hansen, C. W., P. Jensen, And C. SkovsgaARD (2015): “Modern Gender Roles and Agricultural History: The Neolithic Inheritance," Journal of Economic Growth, 20, 365-404.

Howden, S. M., J.F. Soussana, F. N. Tubiello, N. ChHetri, M. Dunlop, And H. MEINKe (2007): "Adapting Agriculture to Climate Change," Proceedings of the National Academy of Sciences, 104, 19691-19696. 
HYSLOP, J. (2014): Qhapaq Ñan, Petroperú.

KEITH, R. G. (1971): "Encomienda, Hacienda and Corregimiento in Spanish America: A Structural Analysis," The Hispanic American Historical Review, 51.

Michalopoulos, S. AND E. PAPAiOANNOU (2011): "Divide and Rule or the Rule of the Divided? Evidence from Africa," NBER working paper.

- (2013): "Pre-Colonial Ethnic Institutions and Contemporary African Development," Econometrica, 81, 113-152.

MilleR, G. (2010): “Contraception as Development? New Evidence from Family Planning in Colombia," The Economic Journal, 120, 709-736.

MURRA, J. V. (1956): The Economic Organization of the Inca State, University of Chicago.

NorTH, D. (1981): Structure and Change in Economic History, New York: W. W. Norton and Co.

NunN, N. (2008): “The Long-Term Effects of Africa's Slave Trades," Oxford UniversityPress.

- (2014): "Historical Development," Handbook of Economic Growth, 2, 347-402.

Pease, F. (2007): Los Incas, Universidad Católica del Peru.

Quiroz, A. W. (2008): Corrupt Circles: A History of Unbound Graft in Peru, Woodrow Wilson Center Press.

Rostworowski, M. (1988): History of the Inca Realm, Cambridge University Press.

_ (1999): “Historia del Tahuantinsuyo,” Institutos de Estudios Peruanos.

Silverblatt, I. (1978): “Andean Women in the Inca Empire,” Feminist Studies, 4, $36-61$.

Spolaore, E. AND R. WACZIARG (2013): "How Deep Are the Roots of Economic Development?" Journal of Economic Literature, 51, 325-369.

SteIn, S. (1980): Populism in Peru: The Emergence of the Masses and the Politics of Social Control, Madison: University of Wisconsin Press.

Xue, M. M. (2018): "High-Value Work and the Rise of Women: The Cotton Revolution and Gender Equality in China," Unpublished. 


\section{APPENDIX}

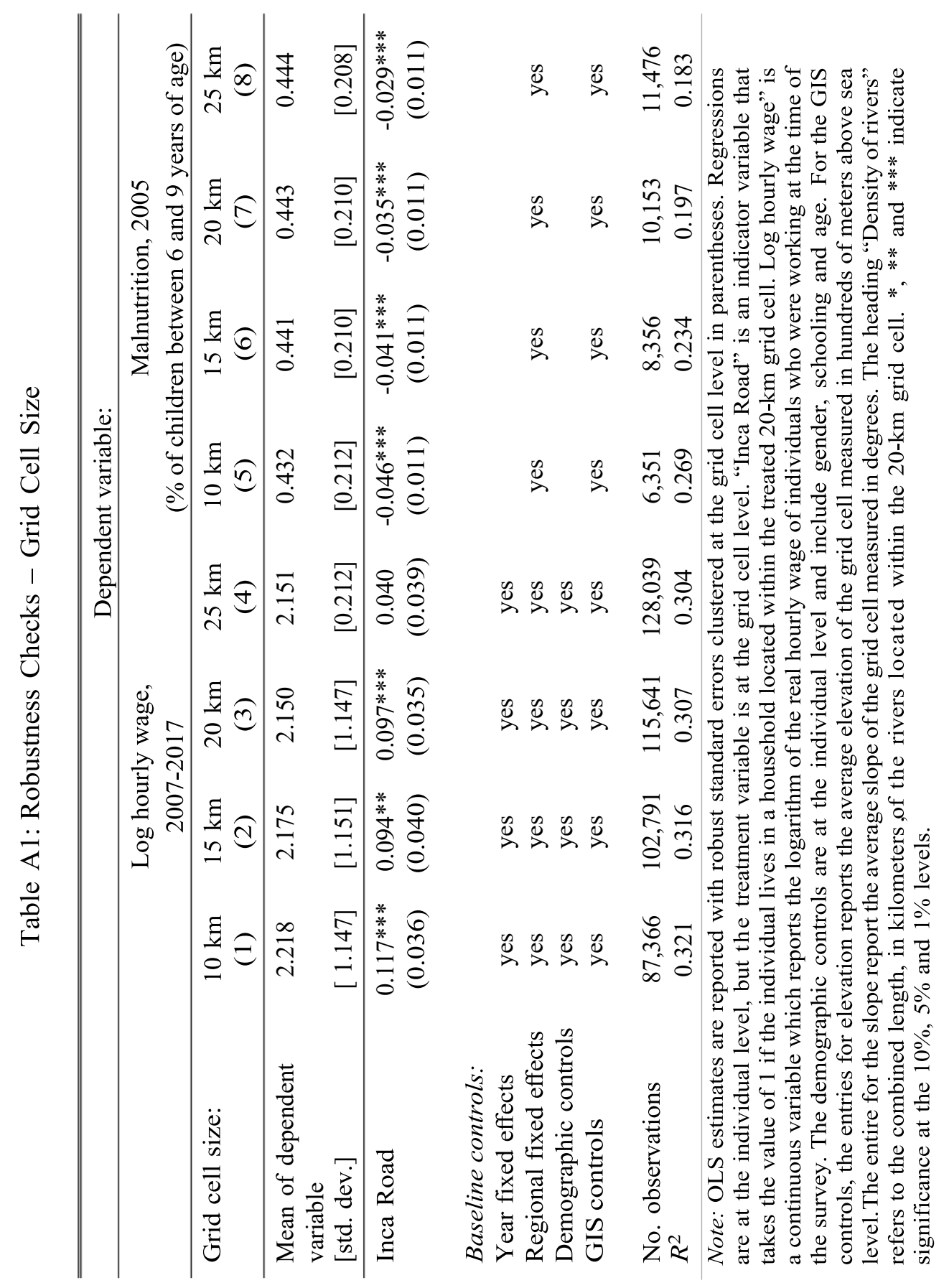




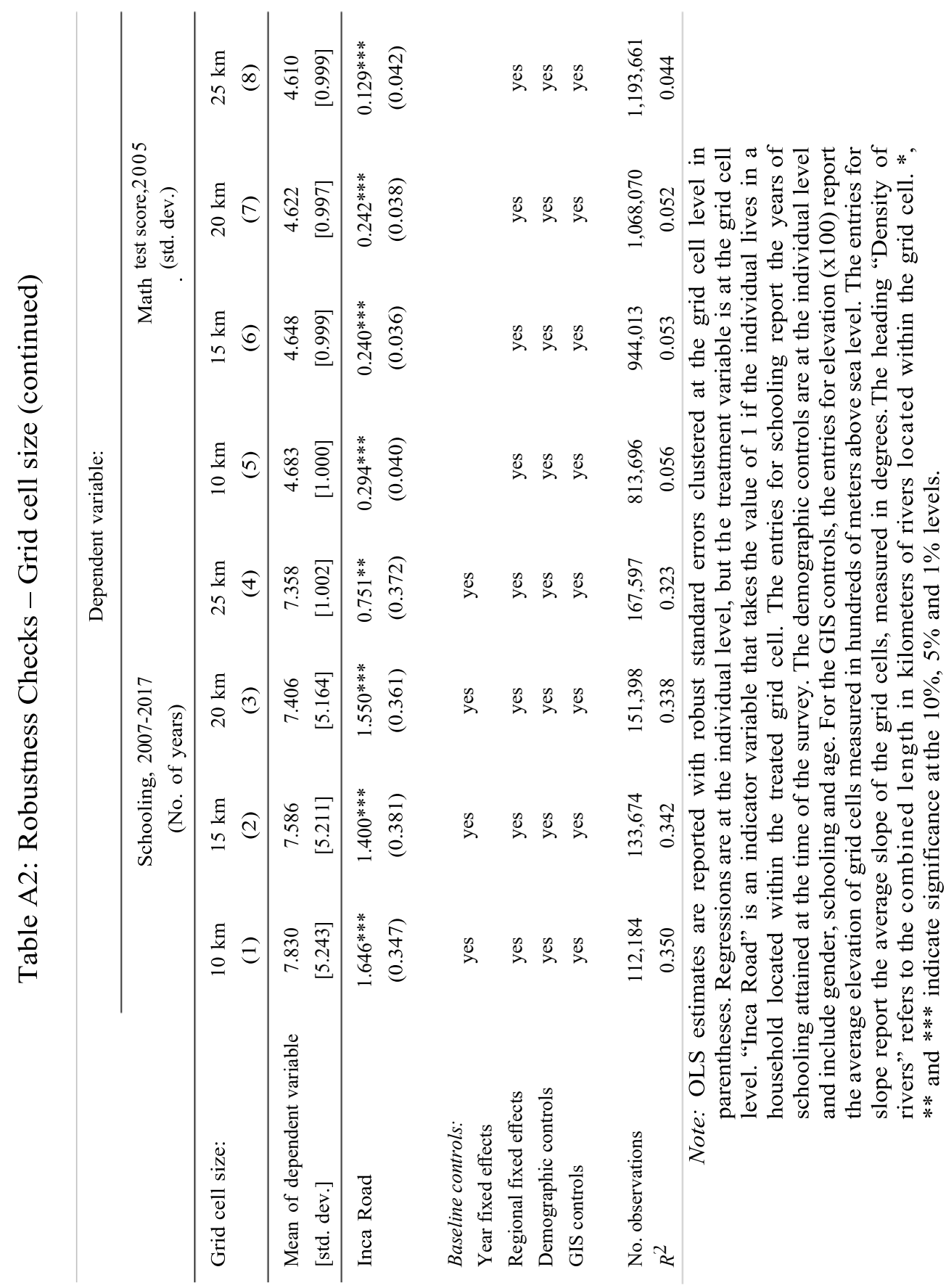

